\title{
Arquitectura Militar y Neoclasicismo. El cuartel de inhábiles de Lugo
}

\author{
Adolfo de Abel Vilela *
}

Resulta conocida la importancia que tuvieron los ingenieros militares en la renovación de la arquitectura de la segunda mitad del siglo XVIII, en especial durante el reinado de Carlos III (1759-1788), período en el que nos encontramos con una serie de tendencias arquitectónicas que hasta ahora se vienen agrupando bajo el denominador común de neoclasicismo, en el que se incluyen corrientes del barroco romano, en la línea de Maderno, Bernini, Galilei, etc., un estilo más depurado en consonancia con el clasicismo renacentista, y formas mucho más simplificadas que se pueden encuadrar dentro de una arquitectura racionalista.

Ya hemos señalado en otra ocasión ${ }^{1}$, que el ingeniero tenía una visión más racional de las formas y más funcional de los espacios. Para ellos la decoración era supérflua e innecesaria desde el punto de vista de la utilidad. Las formas tienen que derivar de una lógica de la construcción y no de una búsqueda de la belleza. Seguían las teorías del veneciano Lodoli que señalaba:

El ornamento no es esencial sino accesorio a la función y a la forma más apropiadas.

El cuartel de inhábiles de Lugo, se puede considerar dentro de esta filosofía. La necesidad de simplificar, de prescindir de la ornamentación, venía impuesta también por dificultades económicas para financiar las obras públicas, como tendremos oportunidad de ver. Al mismo tiempo se construye frente al solar que había de ocupar el cuartel, la iglesia del

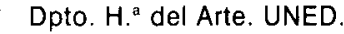

ABEL VILELA, Adolfo, «El tabernáculo de la catedral de Lugo, un ejemplo de neobarroco romano", Espacio, Tiempo y Forma, Serie VII. Historia del Arte, Tomo V. Madrid 1992, págs. 315-338. 


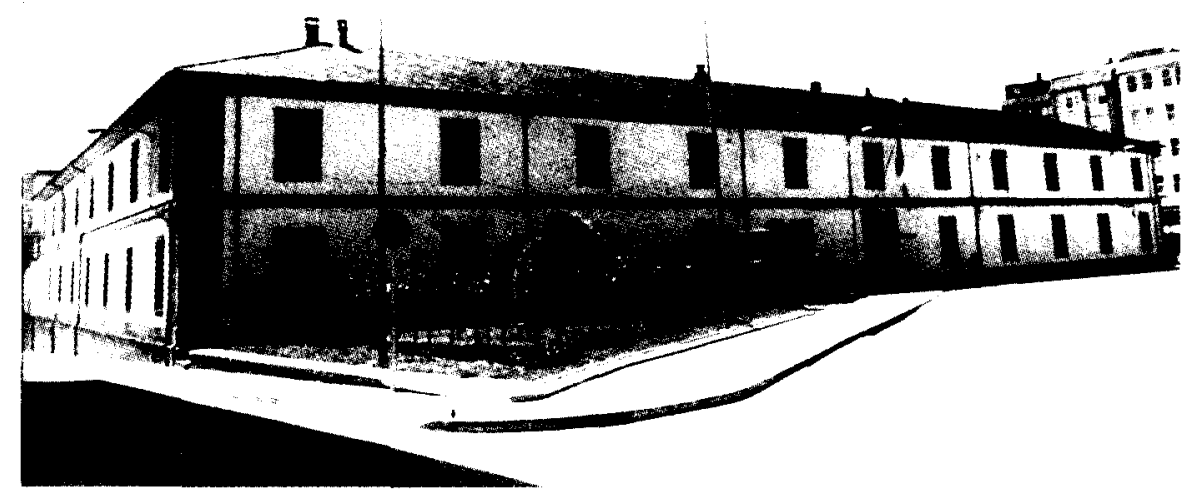

Fig. 1. Fachadas del hospital de inválidos y de la iglesia del hospital de San Bartolomé, terminada en 1752. Dos edificios contemporáneos en los que se puede comprobar la distinta concepción que del edificio tenían los arquitectos tradicionales y los ingenieros militares.

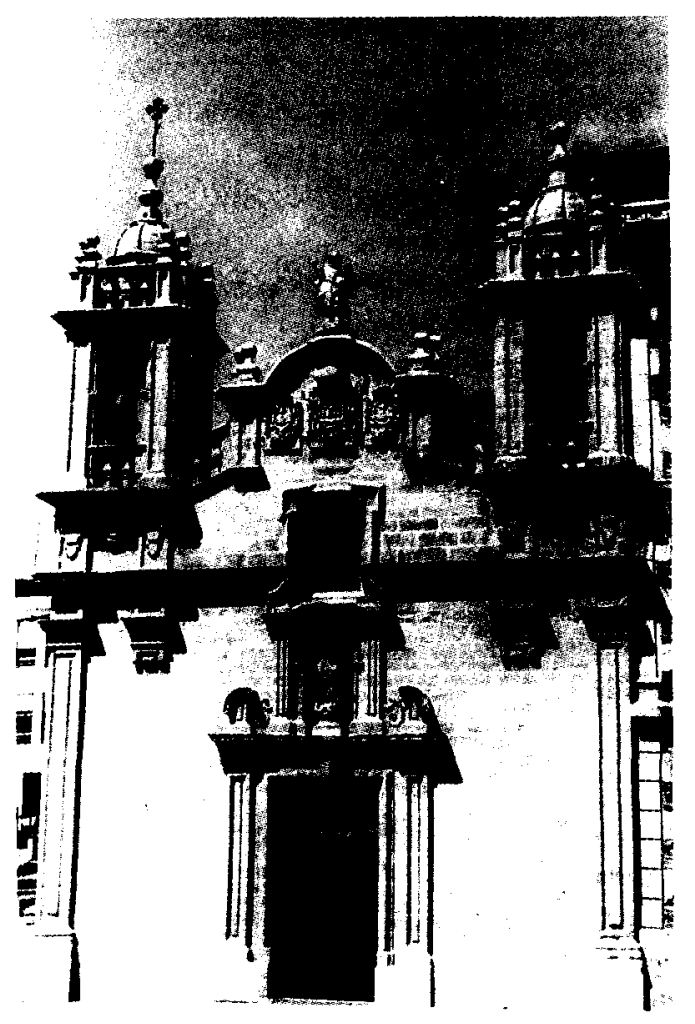


hospital general de la ciudad o de San Bartolomé, de autor anónimo, aunque se supone que del círculo del arquitecto compostelano fray Miguel de los Mártires, que con Alexos Frieixo reconstruía el acueducto romano por orden del obispo fray Francisco Izquierdo. Resulta curioso ver como la fachada de este edificio se ornamenta de acuerdo con el estilo del llamado barroco de placas compostelano, aspecto que pone en evidencia la distinta valoración que de la ornamentación tenían en este momento los arquitectos y los ingenieros militares.

\section{ANTECEDENTES}

El 28 de abril de 1745 , se modificaban las ordenanzas de 31 de enero de 1734 , por las que se creaban treinta y tres regimientos de Milicias. El rey Felipe $V$, a la vista de la utilidad y experiencia de los Inválidos Militares, decide incorporarlos como cuadros de mando. Los componentes de estos regimientos que habiendo servido durante más de doce años quedasen inutilizados para el servicio, serían acreedores a la declaración de inválidos.

Los regimientos de inválidos se organizan por Real Orden e Instrucción de 7 de julio de 1732 y posteriores. Así, el 20 de mayo de 1748, se dictan las "Ordenanzas para el establecimiento de las Compañías de Artilleros Inválidos y sueldos que deben gozarm ${ }^{2}$. En ellas se determina que todos los inválidos de Artillería que se encontraban en los batallones o regimientos de Inválidos, se agruparían formando tres compañías, ubicándose cada una de ellas en Cataluña, Valencia y Galicia.

En el reinado de Carlos III, los inspectores de "Armas" eran lo\$ que proponian al rey pasar a retirados o disfrutar de la gracia de "Inválidos". Las Ordenanzas de 13 de febrero de 1761, en el artículo XXV, dice que serán acreedores a cédulas de Inválidos el que, "por herida recibida, u otro accidente de imposibilidad, ocasionada en acción precisa del servicio, no esté en aptitud de proseguirle, y los que habiendo servido veinte años efectivos en tiempos de paz, sin intermisión, o menos si tuvieran diez campañas, estén cansados ya, y fuera de edad de continuarle; pues estos, aún sin achaques habituales, ni de circunstancias de herida, tendrá derecho a esta gracia" ${ }^{3}$.

Servicio Histórico Militar. Ordenanza y Decreto. Tomo III, pág. 130.

Servicio Histórico Militar. Ordenanza y Decreto. Tomo IV, pág. 231. 
El 24 de enero de 1753, se dicta una Real Instrucción por la que se establecían los regimientos de Inválidos de Valencia y Cataluña en la ciudad de Toro, donde estaba establecido el regimiento de Inválidos de Castilla. El motivo es la organización de las compañías de Artilleros Inválidos. Al separarse de los regimientos los inválidos de artillería quedaban tres batallones con dieciocho compañías, que se verán reducidas a nueve.

Desaparecidas las causas que llevaron al establecimiento de la residencia fija de los «Inválidos" hábiles e inhábiles en esta ciudad, lejos de sus lugares de naturaleza, Carlos III decide una nueva reorganización que se lleva a cabo el 28 de mayo de 1761, a través de un "Reglamento para la reducción de los cuerpos de los Inválidos a compañías sueltas de esa clase y establecimiento de los inhábiles en Sevilla y San Phelipe". En esta disposición se contempla que los cuatro cuerpos de "Hábiles" establecidos en las provincias de Castilla, Galicia, Andalucia, y Extremadura, se dividian en compañias sueltas.

Los "Hábiles" quedan repartidos en Madrid, Castilla la Vieja, Valencia, Navarra y Guizpúzcoa, Andalucía, Galicia, Extremadura, y las compañías de Artilleros de Inválidos. Los “Inhábiles» quedan organizados en veintiséis compañías: ocho en Sevilla, siete en Lugo, tres en Toro y ocho en San Felipe (Valencia).

El uniforme que llevaban los “Inválidos» hábiles e inhábiles del Ejército en esta época, estaba compuesto por sombrero con presilla y galón de estambre amarillo, corbatín redondo negro, casaca y calzón de paño azul turquí, el cuello y las vueltas de las mangas, blancas; la chupa y el forro de los faldones, blanco; botín alto de color blanco y con liga de cuero negro.

\section{LA NECESIDAD DE UN CUARTEL}

La expansión urbana de Lugo hacia el $\mathrm{NE}$, da un nuevo paso en la segunda mitad del siglo XVIII con la construcción del Hospital de los Inválidos, al que se le denominará unas veces como cuartel y otras como hospital. Es frecuente la de Casa de Inválidos Inhábiles. Durante la Guerra de la Independencia se le llamará Hospital de San Fernando.

Su construcción dará lugar a una manzana entre el campo del Hospital de San Bartolomé y la Rúa Nova, un lugar despoblado que sólo tenía dos o tres casas en la calle del Sol, a la que daría el tramo $\mathrm{N}$ del edificio. $\mathrm{De}$ esta forma el área se transforma en una zona de servicios sanitarios, precisamente por su separación de la aglomeración urbana. 
Tenemos que remontarnos al 23 de enero de 1751 para hablar de los primeros intentos de construcción de un cuartel en la ciudad. En el consistorio celebrado ese dia, se habla del agravio que recibia la tropa «tanto por la incomodidad de las casas que le sirven de cuartel, por ser muy reducidas, cuanto por hallarse dispersa sin aquella unión que corresponde a vivir acuartelados y bajo la disciplina militar" ${ }^{4}$.

Los vecinos sufrian más incomodidad a través de la llamada contribución de utensilios, que tenían la obligación de facilitar a la tropa paja, luz y cama, siendo desalojados de sus habitaciones "y además de esto, como las casas que reciben la tropa son de poca resistencia, a breve tiempo se arruinan y quedan inhabitables, como se ve en algunas que ocupó el Segundo Batallón de Cantabria, que se halla en esta ciudad" 5 .

Los alquileres y las reparaciones alcanzaban una cantidad importante de dinero, aumentándose el daño uarruinadas las casas, se va despoblando la ciudad». Lugo era lugar de paso obligado para las tropas que entraban en el reino de Galicia, motivo por el cual el Ayuntamiento había solicitado en varias ocasiones que se construyesen cuarteles, petición que se vuelve a reproducir "para hacer y fabricar unos decentes cuarteles para acomodar un regimiento de infantería y poder elegir el sitio más cómodo sacándolo a cualquier dueño, pagándole su valor a justa tasación» ${ }^{6}$.

La financiación se obtendría mediante reparto entre los estados noble y llano de la capital y provincia. Se acordó escribir al capitán general para pedirle que mantuviese en ella el batallón de Cantabria, ya que cambiarlo por otra tropa causaba perjuicios «pues como la ciudad es de corta población y escasa de habitaciones antes de que la tropa lo reconozca, trae en contínuo movimiento a los naturales" ${ }^{7}$.

Realizar el servicio de bagajes en el invierno era muy dificultoso por el mal estado en el que se encontraban los caminos y las crecidas de los ríos que tenían que vadear en algunas ocasiones, produciéndose pérdidas en los ganados y en los mismos bagajes.

El día 3 de marzo contestaba a la solicitud el marqués de la Ensenada, diciendo que había sido muy del agrado real el pensamiento, "pero como la idea necesita de más serias reflexiones, formándose antes el proyecto del cuartel con el tanteo del coste que tendrá y tiempo que podrá durar

Leg. 76. Actas capitulares de 175i. Consistorio 23-01. AHP de Lugo A.

Ibidem.

Ibidem.

Ibidem. 
la obra, quiere SM que VS trate y acuerde luego el asunto con el intendente de esa provincia» ${ }^{8}$.

Acordaron escribirle a A Coruña, adjuntándole una copia de la carta y pidiéndole que diese las oportunas providencias para que tuviese efecto lo ordenado por el rey. El 24 de marzo recibian la contestación de don José de Avilés, solicitando que le enviasen «el proyecto en que se fundó, el plan de su formación, los medios con que deba ejecutarse, el tanteo de la costa que tendrá, y el tiempo en que deberá tenerse acabado y concluido el todo de tan loable, importante y conveniente obra" ${ }^{9}$.

En vista de ello se nombra a don Andrés de Mosquera y don Pedro Vicente Sanjurjo para que acordasen «el sitio más proporcionado para el fundo de los cuarteles, comodidad de la tropa, y quietud del pueblo, su valor y estimación, el proyecto formal de todas las circunstancias que previene SM, y el poder valerse del maestro o personas que se necesitare para la mejor formación de todo lo referido y sus incidencias, consultando a la Ciudad los reparos que tuvieren convenientes e inconvenientes para la mejor disposición de este edificio y su efectuación" "

Pasaron dos meses y medio sin que el intendente volviese a tener noticias "del estado de este pensamiento" por lo que acordaron contestarle adjuntando el proyecto con el plan de la obra «el que no se pudo despachar más antes así por haberse hallado ausente el maestro que la delineó, como por las reflexiones que fue preciso hacer" ${ }^{11}$. El 12 de julio acusaba haber recibido la documentación y el 27 decía que ya la había examinado, encontrando que el cuartel que se proponía era muy costoso y poco cómodo para la tropa:

...el proyecto tiene pocas condiciones aceptables, especialmente los que trascienden a otra provincia fuera del continente de esa, las que vulneran a privilegiados y otros expuestos con generalidades ${ }^{12}$.

Como estaba interesado en la obra dispuso «que uno de los mejores y más prácticos ingenieros que tiene el rey en este reino, formase una idea arreglada a las demandas de la especie, y conforme a otros cuarteles del reino y a la conveniencia de la tropa, evitando al mismo tiempo gastos supérfluos» ${ }^{13}$.

\footnotetext{
Ibidem. Anexo consistorio 7-03.

Ibidem. Anexo consistorio 27-03.

Ibidem. Consistorio 27-03.

Ibidem. Consistorio 8-07.

Ibidem. Anexo consistorio 31-07.

Ibidem. Anexo consistorio 31-07.
} 
Se habia reducido a la mitad de sus dimensiones acompañando los dos proyectos para que los cotejasen. Les recomendaba que era conveniente "que se tenga premeditado el paraje donde debe hacerse el cuartel, con la condición que sea sitio sano, con ventilación bastante, y en paraje que no incomode a la tropa para su uso ni al público para los suyos, recíprocamente, con la propia relación hacia los vecinos" ${ }^{14}$.

Comisionaron al miembro del Ayuntamiento don Francisco Seoane que estaba por aquellos días en A Coruña, para que se entrevistase con el intendente y llegase a un acuerdo. Pero este no lo pudo hacer y el 21 de agosto acordaron que fuese el escribano, el cual invirtió diecinueve días en realizar la comisión que le encargaron.

El 4 de enero de 1752, el intendente del reino de Galicia don José de Avilés, escribe al Ayuntamiento desde A Coruña, adjuntando una copia de la comunicación enviada por el marqués de la Ensenada el 27 de noviembre de 1751 , en la que decía haber recibido la nueva representación de la ciudad de Lugo sobre la construcción de un cuartel «según la planta que acompaña; y aunque no parezcan convenientes los arbitrios con que propone costear esta obra, lo haré presente a SM con lo que en su asunto expone V.S. para su real resolución" ${ }^{15}$.

El 17 de enero hay una nueva comunicación del marqués en la que decía que "no viene SM en conformarse en que se efectúe con los medios que se proponen" ${ }^{16}$ por 10 que el intendente pide al Ayuntamiento sus ideas para que juntamente con las suyas obtuviesen el mejor éxito.

\section{EL HOSPITAL DE LOS INVÁLIDOS}

El proyecto quedó paralizado. No volvemos a tener noticias importantes hasta el 17 de julio de 1756. En el consistorio celebrado ese día se da lectura a una comunicación de don José de Avilés, en la que decía que tenía algunos antecedentes para que se instalase en la ciudad un batallón de los inválidos inhábiles, compuesto por cuatrocientos o quinientos hombres, con sus oficiales.

Para poder influir en su construcción necesitaba saber si había o no en la ciudad cuarteles para acomodarlos, aunque fuesen provisionales, encargando del reconocimiento al regidor don Andrés Mosquera Valdivie-

14 Ibidem. Anexo consistorio 31-07

15 Leg. 77. Actas capitulares de 1752. Anexo consistorio 8-01. AHP de L.A.

${ }_{16}$ Ibidem. Anexo consistorio 22-01. 
ADOLFO DE ABEL VILELA

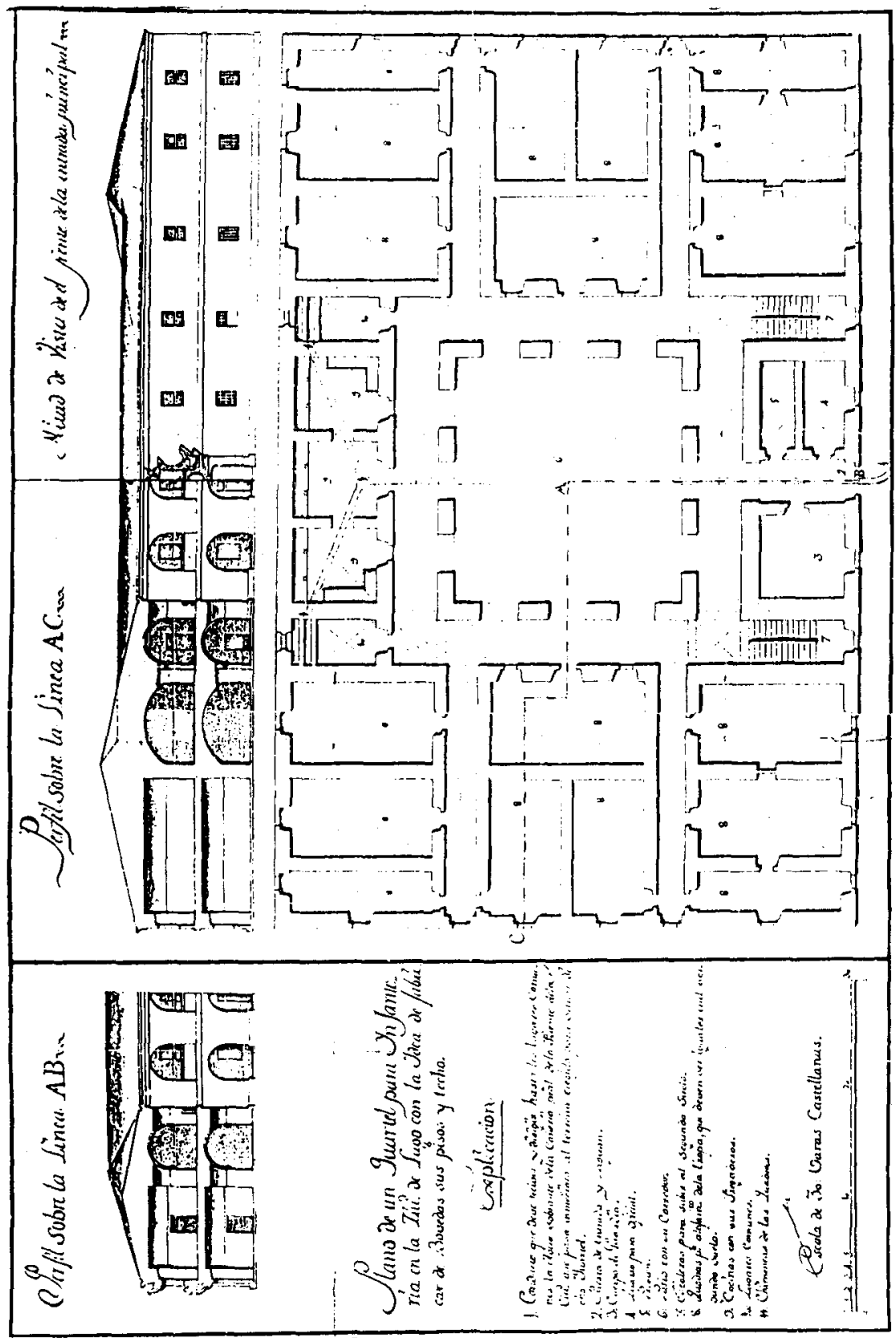




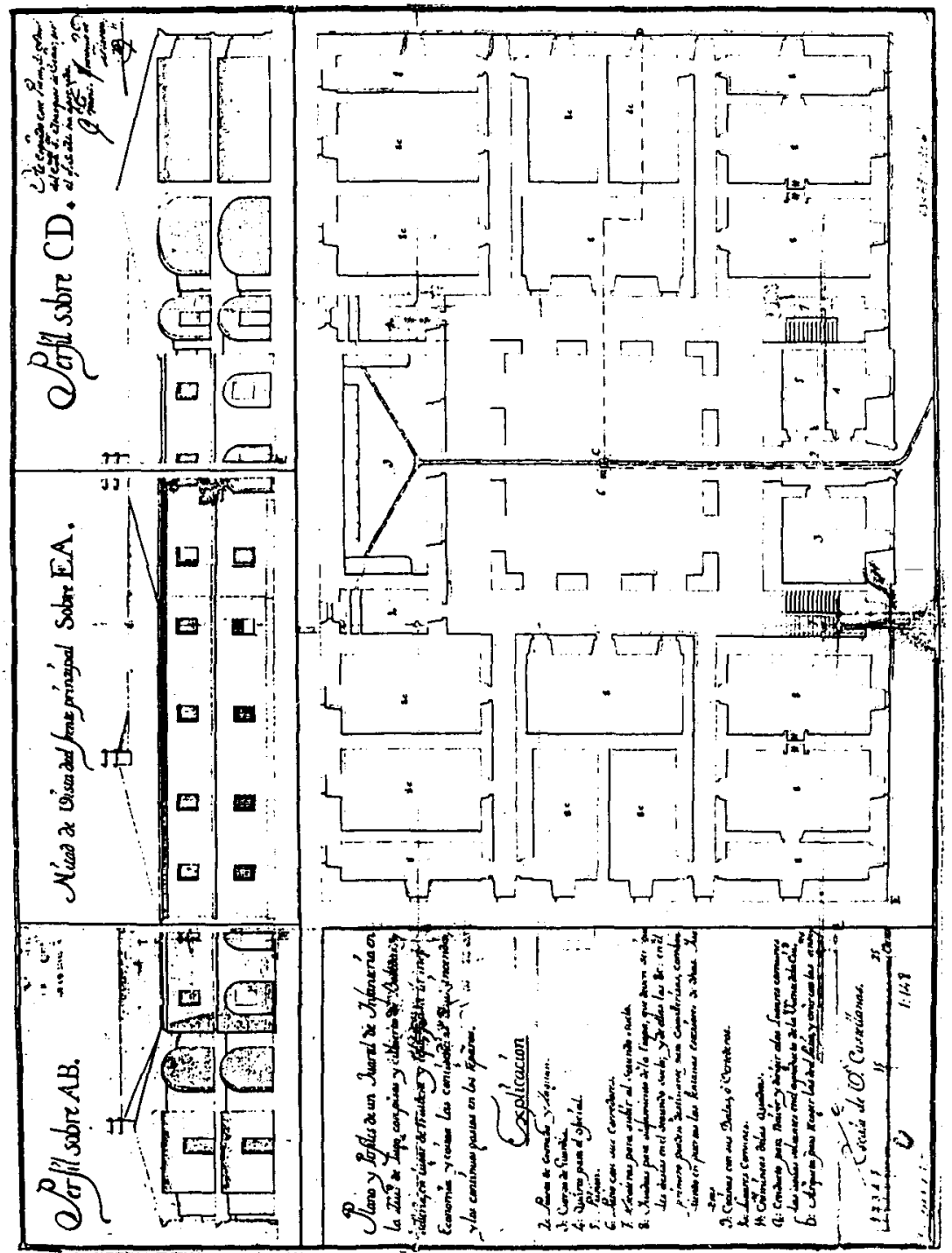

8

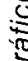

8

0

옹

ब)

0
1

옹

今

8

오ำ

ธ

홍ํㅇ

$\frac{\pi}{2}$

क

s

号热

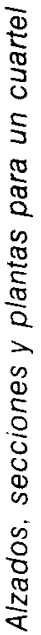

iv

is 
so y Montenegro. Se contaba con el importante apoyo del capitán general, marqués de Croix, ya que había otras ciudades que se lo disputaban.

El Ayuntamiento dio su respuesta favorable el día 31 de julio, y el 11 de agosto el intendente comunicaba haber dado el curso correspondiente «al influjo con que comencé esta idea contra el apoyo que se tenía granjeado el partido de los que inspiraban a favor de Pontevedra, y VS no dude que haré cuanto pueda, y hoy más en que observo también propenso a este caballero comandante general, en que supongo no tendrá ya muchas acciones, y de donde se espera la resolución" ${ }^{17}$.

Prometía todo su apoyo y advertía que "será menester tener algo de paciencia, disimular mucho y no detenerse en los reparos y embarazos que se presentarán al primer ingreso" ${ }^{18}$.

El comandante general había llegado recientemente a Galicia, según se desprende de la carta del intendente y del acuerdo tomado por el Ayuntamiento en el consistorio del día 18 de agosto, en el que comisionaban a los capitulares don Juan José Osorio y don Manuel Valcarcel para que pasasen a «A Coruña a la orden de esta Ciudad a dar la enhorabuena de su empleo al excelentísimo señor comandate general de este reino" ${ }^{19}$. Este acto de cortesía se fue dilatando, tal vez intencionadamente para poder aprovechar la visita para plantear la cuestión del cuartel. Por indisposición de don Juan José Osorio acudió con él otro regidor, don Pedro Vicente Sanjurjo. La audiencia tuvo lugar el 12 de noviembre, entregándole el plano del cuartel al marqués de Coix.

Una de las formas de asegurar su instalación en Lugo, era la de trasladar los inválidos a la ciudad, por lo que la primera autoridad militar dio la orden de buscar alojamientos en cuarteles provisionales «contemplando que deberán ser capaces y cómodos para cuatrocientos y cincuenta 0 quinientos hombres, aguardando entender por VS que están prevenidos, a fin de poder yo dar la orden para que esa tropa se ponga en marcha" ${ }^{20}$.

Es evidente que el aumento de más de quinientos habitantes por el traslado aquí, no sólo de los inválidos, sino también de algún familiar que los atendía, tenía una enorme imporancia económica para la ciudad que en aquel momento tendría unos 1.500 habitantes.

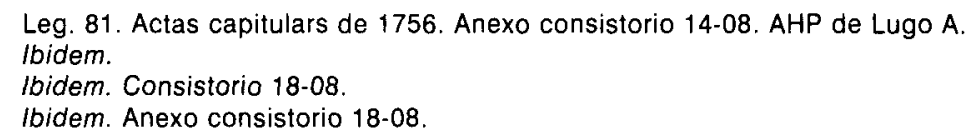


Se esperaba que tanto los soldados como los sargentos inválidos llegasen en la última semana de agosto, por lo que se hacía necesario preparar los suministros. El intendente advertía que en cuanto a carnes y demás abastos, no se viviese con escasez y miseria, "sin aumento de precios, porque indispondría la armonía a que hoy se halla tan templada y concertada" ${ }^{21}$ recomendándoles que no desesperasen si los oficiales estaban más de los tres días reglamentarios en los alojamientos que tenían que facilitarles.

Se buscaron casas, en las que fue preciso hacer algunas reparaciones, razón por la que entendían que no estarian dispuestas para recibir a los inválidos hasta el primero de septiembre. El capitán general había ordenado la salida de Santiago el día 25 ó 26, por lo que se rogaba al Ayuntamiento que en el supuesto de llegar antes, les buscasen alojamiento en donde pudiesen estar con alguna comodidad.

Había algunas casas destinadas en las que ocuparían una cama cada tres hombres, como era habitual entre la tropa, pero en el caso de los inválidos estaba ordenado que fuesen dos, por lo que necesitaban preparar alojamiento para un tercio más. La solución era proceder al desalojo de los ocupantes de las casas y después repararlas. Era tan grande la escasez de viviendas que tuvieron que recurrir al desalojo de los tambores y sargentos de milicias, trasladándose a otra casa. Pero el sargento mayor, don Felipe Diego Saavedra, puso una serie de pretextos para permanecer en la que tenían, en vista de lo cual el Ayuntamiento lo puso en conocimiento del capitán general y del intendente, disponiendo la autoridad militar que se trasladasen a las casas que les destinaban, que eran dos situadas en la Rúa Nova.

El sargento propuso que les facilitasen unos locales de las «casas consistoriales" que estaban situados "en la oficina o lonja terrena que se halla en Consistorio, con su entrada por su claustro o zaguán, a la parte del Norte, y otra plaza baja, que separada se halla enfrente de la otra, para cocina» ${ }^{22}$. Acordaron concedérselas y en el caso de que fuese preciso la prisión de algún oficial le facilitarian la oficina destinada para los caballeros capitulares del Ayuntamiento.

La reforma militar efectuada diez años después, seguía contemplando la obligación de las capitales de dar ula casa cuartel para el destacamento de sargentos, cabos, tambores y pifanos, que ha de haber precisamente

21 Ibidem.

22 Ibidem. Consistorio 10-09. 
en cada una; otras proporcionadas y decentes al sargento mayor y ayudantes, y sala capaz y cómoda para custodiar y conservar el armamento, todas por sus justos alquileres» ${ }^{23}$.

Esta penuria de viviendas o de edificios con un mínimo de dignidad, que nos da una visión de lo que era la ciudad desde el punto de vista urbanístico, hizo que llegasen enseguida las llamadas de atención del capitán general. La primera se produce el 22 de septiembre. Manifestaba que por informes y quejas que le habían dado, sabía que los inválidos no estaban atendidos como se debía, y que si no se recogían las deficiencias, se podría malograr tan provechoso proyecto. El 25 de septiembre el Ayuntamiento contestó diciendo que ya se habían subsanado las deficiencias y que deseaban que se construyese un cuartel a propósito para el alojamiento de los inválidos.

La segunda se produce después del informe elaborado el 10 de octubre por el inspector de inválidos don Jerónimo de Villava, aprovechando su paso por la ciudad. Éste, acompañado del comandante don José Moscoso, varios capitulares y el alcalde más antiguo, gira una visita a las casas destinadas a cuarteles, haciendo la observación de que los inválidos pudiesen permanecer usin su total exterminio, o al menos sin mucha penalidad, así por no hallarse de venta las legumbres, carne sustanciosa y más víveres que necesitan para su regular alimento, como por la incomodidad de los edificios destinados a su estancia, queriendo que la hagan en piezas bajas y húmedas, por estar al desnudo suelo, y en los desvanes, sin más abrigo que las losas pizarras, mal unidas que los cubren y dejan libre la impresión de la humedad y frío correspondiente a los temporales y natural situación del país, todo opuesto al reparo y fomento que necesitan los individuos que los han de ocupar para poder sobrellevar la penalidad de su edad avanzada y de sus achaques" ${ }^{24}$.

En vista de esto el inspector solicitaba que fuesen trasladados a otro pueblo más adecuado. El capitán general hacía ver al Ayuntamiento la especial característica de los inválidos "que debe ser atendida por el mérito de sus circunstancias y servicios, y por su ancianidad; y que por estos y otros títulos, se hace acreedora de los esmeros de la piedad cristiana, cuanto más a las providencias que mis facultades puedan aplicarles, correspondiente a dejar correspondida la intención de $\mathrm{SM}^{25}$.

23 Reglamento del nuevo pie en que SM manda se establezcan los cuerpos de Milicias Provinciales, aumentándolos hasta el número de cuarenta y dos regimientos en las provincias de la corona de Castilla. Madrid 1766. Artículo VI

24 Leg. 81. Actas capitulares de 1756. Anexo consistorio 16-10. AHP de L.A.

25 Ibidem. 
Pedía que antes de comenzar el invierno se acomodasen bien a los que estaban ocupando casas de vecinos pobres, durmiendo unos y otros en el suelo, recordándoles que no dejasen de la mano la construcción de un cuartel competente.

El Ayuntamiento le contestó diciendo que había procurado facilitar el mejor alojamiento, pero dejaba entrever que había un interés especial por deslucir su labor debido a que la cintención de la tropa es mudar de país este pensamiento" ${ }^{26}$.

Las malas condiciones en las que continuaron viviendo los inválidos dio lugar a nuevas quejas ante el Ayuntamiento. Así, el 27 de diciembre de 1757, el marqués de Croix escribía desde A Coruña, diciendo que le comunicaba don Martín de Milla, comandante del cuerpo de inválidos inhábiles, que a pesar de los reiterados avisos al Ayuntamiento para que arreglase las casas que se utilizaban como cuarteles en las que llovía "con mucho exceso", le rogaba que por lo menos atajasen la introducción de las lluvias.

Le contestaron diciendo que «la Ciudad siente mucho se haya molestado su grande atención por parte del comandante de inhábiles cuando a este le consta y a don Pablo Ferrás, sargento mayor del mismo cuerpo, los buenos oficios de la Ciudad en la mayor comodidad de la tropa y precisos reparos de las casas que habitan en cualidad de cuartel habiéndose reedificado algunas, y facilitando los materiales para otras sin que lo riguroso de la estación permitiese mayor adelantamiento, pudiendo su excelencia asegurarse de que la Ciudad no faltará en cuanto esté de su parte en proseguir en el alivio de esta tropa, no pudiendo ejecutar el hacerle presente que el referido comandante no tuvo razón para adelantar sus oficios en oposición de lo mismo que está experimentando. Y este motivo le es muy suficiente para solicitar la proyectada fábrica de cuarteles que está pendiente, suplicando a su excelencia se sirva promover eficacia de esta obra tan importante a la comodidad de la tropa y aún del pueblo, y en el entretanto no suspenderá sus oficios en lo que corresponda a su mejor establecimiento" "27.

\section{LA UBICACIÓN}

En 1756 se iniciaron las gestiones para conseguir un solar adecuado en el que se pudiese construir el edificio. Se buscó en la zona $\mathbf{N}$ del

26 Ibidem. Consistorio 16-10.

27 Leg. 83. Actas capitulares de 1758. Consistorio 7-01. AHP de L.A. 
recinto amurallado, entre el hospital de San Bartolomé y la Rúa Nova. Habian escrito a don Luis Fernando de Varela y Saavedra, que se encontraba en Linares, interesándose por una cortiña que poseía en la Rúa Nova. El propietario contestó al Ayuntamiento el día 29 de agosto, señalando que "habiendo reconocido los papeles de ella halló ser de mayorazgo, cuyo embarazo me priva de poder asentir en lo que VS tiene determinado, porque como en aquella inmediación tengo casas a las que sirven de huerta dicha cortiña, y enajenada esta, me quedarán sin casero que viva en aquellas» ${ }^{28}$. Esto demuestra la importancia que se daba a la huerta, ya fuese contigua, próxima o alejada de la casa, elemento fundamental para la autarquía de sus habitadores. No obstante les indicaba que podrían tratar el asunto personalmente a finales del mes de septiembre, ya que esperaba encontrarse en la ciudad.

Otra gestión fue realizada por el regidor don José Baamonde, ante don Miguel de Montenegro al que plantearon que "condescendiese el ceder a la Ciudad una cortiña hacia la puerta Nova para en ella fabricar cuarteles" ${ }^{29}$. Como la finca era de vínculo, dio orden a su capellán don Tomás Pardo, para arreglar la pensión, dándole sus poderes para que se pudiese efectuar el contrato.

El 4 de noviembre de 1758, el intendente don Juan Felipe de Castaños, escribía desde A Coruña para comunicar que se desplazaría a Lugo el arquitecto y asentista de la Real Cárcel, don Francisco Antonio de Zalaeta, para que reconociese «el paraje que fuese más a propósito para la fábrica de ese cuartel" ${ }^{30}$.

Este arquitecto, que estaba también en las obras del arsenal de Ferrol, emite un informe el 11 de diciembre en el que decía que había efectuado el reconocimiento acompañado de varios capitulares, encontrando que "la situación y terreno más a propósito para la construcción de este edificio, y con más ventaja a otros por las circunstancias que en él se hallan, la inmediata al hospital de San Juan de Dios y el de una heredad de cultivo que hace frente a su iglesia y campo, y confina con la calle que dicen del Sol, en el cual se ha de comprender, según lo que se me ha enterado del plano, ochenta varas de frente y otras tantas de fondo, cogiendo el formal cuadro, según to ha delineado, para el que se debe incluir una corta porción de otra heredad que está contigua hacia el lado del convento de Nuestro Padre Santo Domingo, y entre esta y la antecedente media un camino que viene de la calle que dicen Nueva" ${ }^{31}$.

Ibidem. Consistorio 11-10.

${ }^{30}$ Leg. 8-1. Obras Públicas. AHP de L.A.

31 Ibidem. 

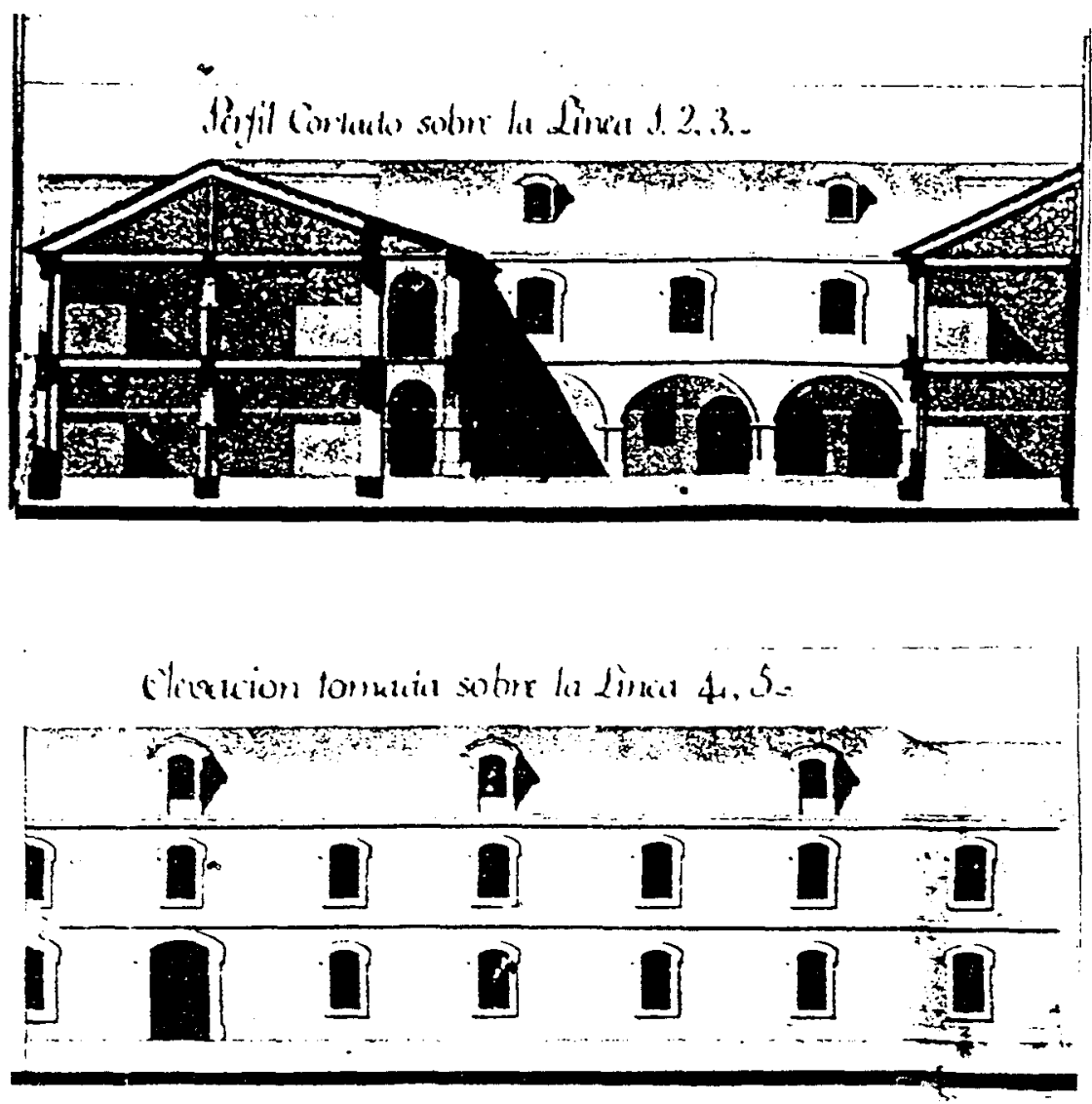

Fig. 3. Detalles correspondientes al patio interior y a la fachada principal del edificio en los que se puede observar la utilización de vanos de arco escarzano moldurados con orejeras en la parte superior. 
Como vemos, se da aquí la situación de la parcela que quedaba comprendida entre la calle del Sol, lado N, y el carril del Indigno, lado S. Al $E$, estaba el campo de la iglesia del hospital, y al W, con terrenos de los edificios que tenían sus fachadas a las calles del Sol y del Indigno.

En el momento de escoger el terreno, el plano del edificio ya había sido reformado por el arquitecto de A Coruña don Martín Gabriel, como ya hemos señalado anteriormente. Fue después perfeccionado con tanteo y regulación del coste de materiales por los maestros de obras de la Ciudad, enviándose toda la documentación a la corte, indicando, además, los medios que consideraban más convenientes para la financiación de la obra.

Este nuevo reformado va a incluir, además de las seis compañías de inválidos, un batallón de tropa transeúnte de infantería, de ahí que se independicen ambos cuerpos militares. En los planos podemos observar la existencia de dos patios interiores a los que se accede por zaguanes y puertas independientes, de suerte que la fachada principal contaría con dos puertas de entrada.

La organización del edificio en altura se hace con dos cuerpos, separados por una moldura en cincha, pero se aprovecha el bajo cubierta con seis buhardillas por tramo. Otra novedad es la utilización del arco escarzano con orejeras para los vanos, semejantes a los utilizados en edificios de la plaza de Pío XII en el atrio grande de la catedral. En los patios, el corredor inferior es de arco carpanel y bóveda de cañón, mientras que en el cuerpo superior se colocan ventanas.

El predio seleccionado estaba formado por una cortiña propiedad de don José Pascual de Soto, con una superficie de 3.120 varas, correspondiéndole 5.828 reales y 20 maravedís, pero en octubre de 1779 se volvieron a tasar al ocupársele más superficie, 5.620 varas, con un importe de 950 ducados o 10.450 reales de vellón. Estaba sembrada de nabos, siendo tasados en 160 reales, y cerrada con un muro de pizarra con su portada de granito, excepto el lado $\mathrm{N}$ que tenía el cierre de chantos. En la misma propiedad había dos casetas que estaba utilizando el hospital. Éstas fueron adquiridas por 1.000 reales de vellón para almacén de las herramientas y otros útiles necesarios para la construcción del edificio.

\section{EL SISTEMA DE FINANCIACIÓN DE LA OBRA}

Los maestros de obras de la Ciudad regularon el costo de la construcción en 238.541 reales de vellón, teniendo en cuenta el precio de los materiales del país, siendo la duración de las mismas dos años. Se pre- 


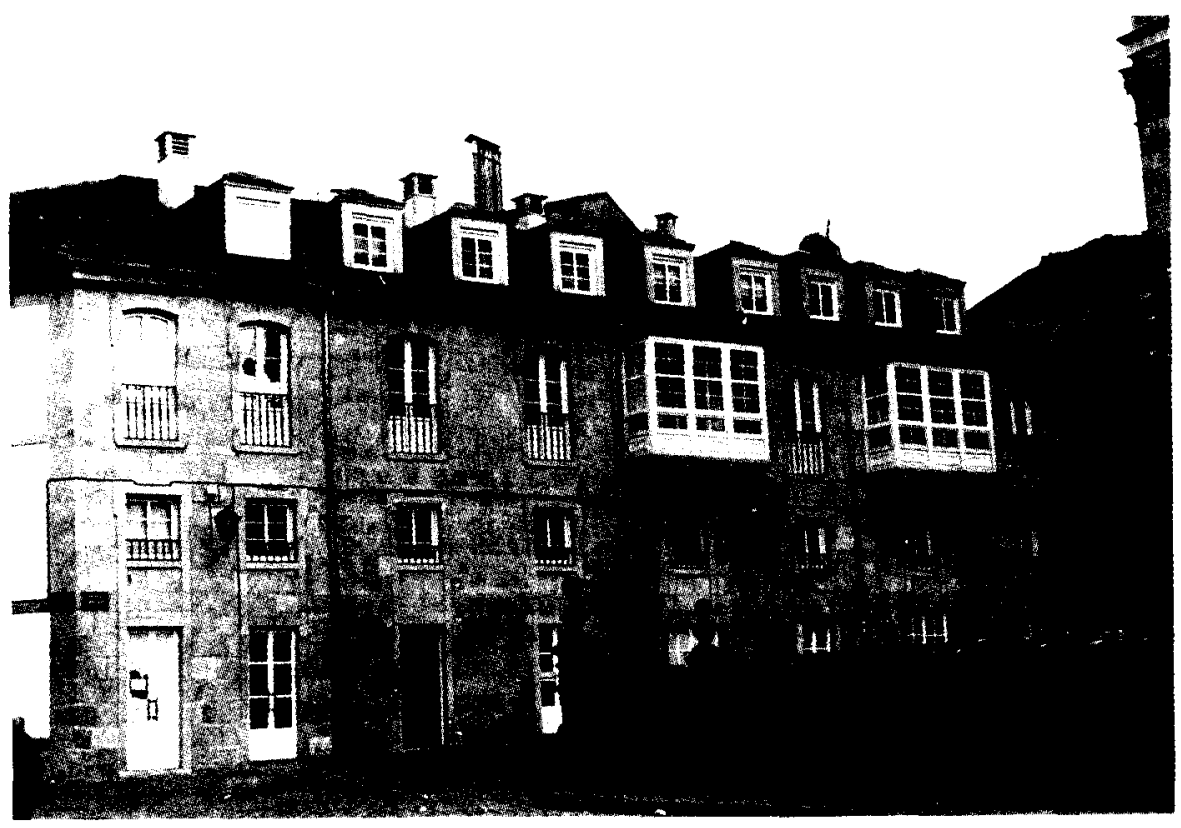

Fig. 4. Edificio neoclásico situado en la plaza de Pío XII de Lugo. Los vanos superiores son de arco escarzano con orejeras.

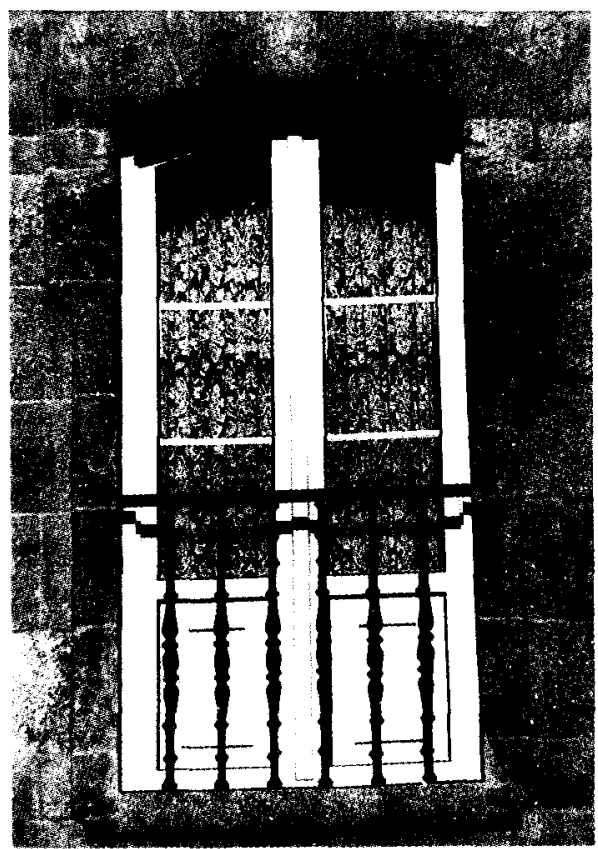


tendía obtener los fondos del indulto de la contribución de utensilios durante dos años "en atención a la grande suma que tienen gastado los naturales en la fábrica del Camino Real, construcción de puentes en la longitud de dieciocho y más leguas, que está contribuyendo a varios acreedores, por sentencia del Consejo, anualmente en cien mil y más reales, además de las contribuciones reales ordinarias y regulares, y que se sigue beneficio al reino que en común contribuye a los alquileres de las casas que en esta ciudad sirven de cuartel al cuerpo de inválidos 0 inhábiles, y al de justicias, que han de ascender a cuatro mil y más reales anuales" ${ }^{32}$.

La ciudad y provincia estaban contribuyendo desde hacía varios años para mejorar la carretera real de Madrid a A Coruña, en unas veinte leguas de longitud, de forma que a partir de entonces podían circular por ella coches, carreterías y caballerías, siendo preciso la construcción de algunos puentes de gran tamaño.

No encontraban otro arbitrio dado que la orografía de la provincia hacía que no tuviese más comercio que el derivado del trabajo del campo. Esta proposición fue rechazada por el capitán general, porque consideraba que la cuota correspondiente a la provincia de Lugo, habría que repartirla entre las otras seis provincias en razón de que al asentista se los tenían que satisfacer por completo, pidiéndoles que discurriesen otro arbitrio para que a la superioridad no le faltase en donde elegir.

Otra de las propuestas fue que los naturales de la ciudad y provincia, por repartimiento entre los estados noble y plebeyo, distribuido en dos pagas iguales a correspondencia del caudal posible de cada uno, sin que por ello se viese perjudicado el privilegio de los nobles.

Para que fuese más llevadera la carga, pedían un indulto en el último año de dos, de aportar en la contribución de utensilios de camas, luz, leña, alquileres de casas de cuarteles, con que se contribuía habitualmente a las tropas acantonadas en el reino de Galicia. La miseria del país no permitía mantener más tropa que la reglamentaria en tiempos de paz, es decir, un batallón de milicianos que llevaba el nombre del Provincial de Lugo.

Se impuso el arbitrio de un cuartillo en arroba de vino del que se recogiese y vendiese al por mayor en la provincia, encargándose la recaudación al intendente don Felipe de Avilés. El decreto de concesión era de fecha 18 de agosto de 1757, y en él se decía que para poder ejecutar

32 Leg. 81. Actas capitulares de 1756. Consistorio 4-12. AHP de L.A. 
la obra con rapidez se adelantarían las primeras cantidades del fondo de fortificaciones, que serían recuperadas una vez que se cobrase lo recaudado.

El 5 de julio de 1758, el intendente Juan Felipe de Castaños, manifestaba en un escrito que la superioridad le pedía información sobre "no haber llevado a efecto el arbitrio de un cuartillo en arroba de vino que hoy se vende por mayor, concedido para la construcción de un cuartel en esa ciudad, y hallándome ignorante de los motivos que puedan haberlo embarazado espero que V.S. me instruya de ellos, dándome al mismo tiempo noticia puntual del proyecto que haya habido para esta obra, paraje destinado para ella, medios propuestos para la recaudación tanto de uno y otro, y cuanto conduzca a que tenga una puntual inteligencia de este asunto" " ${ }^{33}$. Como se encontraba en A Coruña el capitular Pedro Vicente Sanjurjo, acordaron que pasase a informarle sobre lo que pedía.

El 14 de julio escribía de nuevo el intendente, indicando que había recibido facultad del Real Consejo para el arbitrio destinado al cuartel. Había escrito al ministro de la Guerra, de acuerdo con el informe que le facilitara el miembro del Ayuntamieto, don Pedro Vicente Sanjurjo, solicitando la devolución del plano que se había trazado, preguntando si no sería gravoso o útil, que se exigiese la cala del año anterior para aprovisionamiento de materiales y apertura de cimientos, dado que si esperaban a la cala de la cosecha del año, habría pasado el verano.

El Ayuntamiento contestó diciendo que la provincia estaba muy recargada de contribuciones, ya que, además de la del cuartel, estaban contribuyendo con un maravedí en azumbre para la construcción de las casas de audiencia de A Coruña, pidiendo que se solicitase la exención de este último.

Se había pedido la exención del impuesto de medio maravedí en azumbre de vino que le tocaba recaudar en aquel año al igual que a las otras provincias del Reino de Galicia destinado a las obras del palacio y Cárcel Real de A Coruña, añadiendo que consideraba indispensable "la ejecuten los cosecheros de ella y también con lo que les correspondiese pagar por lo respectivo al expresado cuartel según el vino del año pasado y de este» ${ }^{34}$.

El arbitrio comenzó a cobrarse en 1758, siguiendo los dos años siguientes por administración y recaudación de las justicias, pero en 1761,

4 Leg. 8-1. Obras Públicas. AHP de L.A. 
reconociendo el intendente don Andrés Gómez de la Vega, el poco producto que daba, para evitar posibles fraudes decidió arrendarlo, comunicándoselo al subdelegado de Lugo para que procediese a su adjudicación recayendo en don Benito Pablo Díaz, por el tiempo de cuatro años que debían finalizar en la cosecha de 1764. La contrata se hizo por 62.000 reales cada cosecha.

Para la recaudación y custodia de su importe, se nombró al tesorero de Rentas Provinciales en la ciudad, don Felipe Moscoso y Novoa. En 1765, hubo varios recursos de los cosecheros contra el asentista, dando lugar a su cese, de tal forma que el último año del arbitrio fue el de 1764 , recaudándose en total 329.386 reales y 31 maravedís.

\section{LA ELABORACIÓN DEL PROYECTO}

Ya hemos mencionado que hubo unas primeras trazas hechas en Lugo que no satisfacieron al intendente por no adaptarse a las necesidades de la tropa. Después se elaboró un nuevo proyecto en A Coruña en 1751 por uno de los mejores arquitectos que había allí en aquel momento al servicio real. Es probable que el nuevo elaborado en 1756, recogiese algo del anterior confeccionado por uno de los maestros de la Ciudad, posiblemente Domingo Francisco Eytor.

El día 12 de noviembre, aprovechando el acto de cortesía o de bienvenida que la Ciudad ofrecía al nuevo capitán general, le entregaron los planos, «y habiéndolo reconocido, sin embargo que no lo encontró desarreglado, me pareció conveniente hacerlo ver por un ingeniero de esta plaza, quien condescendió conmigo a perfeccionarlo más bien, y lo hizo a mi satisfacción en la manera que manifiesta el plano que ha formado, que va con poca diferencia igual al expresadon ${ }^{35}$.

El día 24 de noviembre se lo remitía al Ayuntamiento para que se lo devolviese, si lo encontraban conforme, acompañado de la correspondiente representación en la que se señalaba los medios que consideraban menos gravosos para que los habitantes de la provincia lo pudiesen financiar.

Este plano había sido elaborado por el ingeniero don Martín Gabriel, según consta en una carta enviada el 21 de diciembre por el capitán general, en la que dice «lo halló de dictamen de estar los precios, no sólo

35 Leg. 81. Actas capitulares de 1756. Anexo consistorio 28-11. AHP de L.A. 
arreglados, sino ventajosos; y que lo será la construcción del edificio, por caudal tan moderado, bien que contempla conveniente aumentar el cálculo, el importe de un pequeño cornisamento de cantería que el plano demuestra, como también el coste de unas rejas de hierro en las ventanas bajas, y que las partidas 3 y 4 , que tratan de hacer de madera los marcos y cargaderos de puertas y ventanas interiores, se considere y ejecute para su mayor duración, de piedra de sillería» ${ }^{36}$.

En los planos se presenta un edificio de dos cuerpos delimitados por una cornisa en cincha. Los vanos son de dintel recto, recogiendo el efecto depurador del racionalismo que elimina todo elemento que denote movilidad, incluso las orejeras del jambaje. Sin embargo se utiliza el dintel escarzano para el vano de la entrada principal, un tanto monumental, aún apegada a la tradición barroca. Ésta se divide en dos cuerpos, concetrándose la decoración en el superior. A la altura de la cornisa de separación, una potente moldura sirve de base a las volutas en forma de rocalla que enmarcan el vano de la parte alta. Un óculo u ojo de buey se sitúa sobre el dintel de la puerta, ocupando parte del ventanal superior.

La organización en planta se hace en torno a un patio central, cuadrado, cada uno de los lados con tres arcos de medio punto por cuerpo. En el zaguán de la entrada se situaba, a la derecha, dos habitaciones destinadas una al oficial de guardia y la otra a prisión. A la izquierda el cuerpo de guardia y a ambos lados las escaleras de acceso a la planta superior. En la parte opuesta las cocinas, fregaderos y comunes. El resto de los huecos se destinaban a habitaciones. Los pasillos o corredores se representan abovedados.

El día 1 de diciembre de 1765, el capitán general, marqués de Croix, comunicó al Ayuntamiento que el rey había ordenado que se procediese a la construcción del cuartel iniciándose la obra, pero a pesar de esta real resolución no se comenzó.

El número de inválidos era menor, debido al tiempo que había transcurrido. Unos habían muerto y otros obtenido licencia para pasar a sus casas, lo cual hacía que peligrase la construcción del edificio "de alto coste con magnificencia, y sólo él capaz y suficiente para recibir dichos inválidos, por no considerar otra proporción, según la situación de este pueblo y miseria del país, para la subsistencia de tropa en los tiempos que no sean de guerra" ${ }^{37}$.

36 Ibidem. Consistorio 25-12.

${ }^{37}$ Leg. 8-1. Obras Púolicas. 


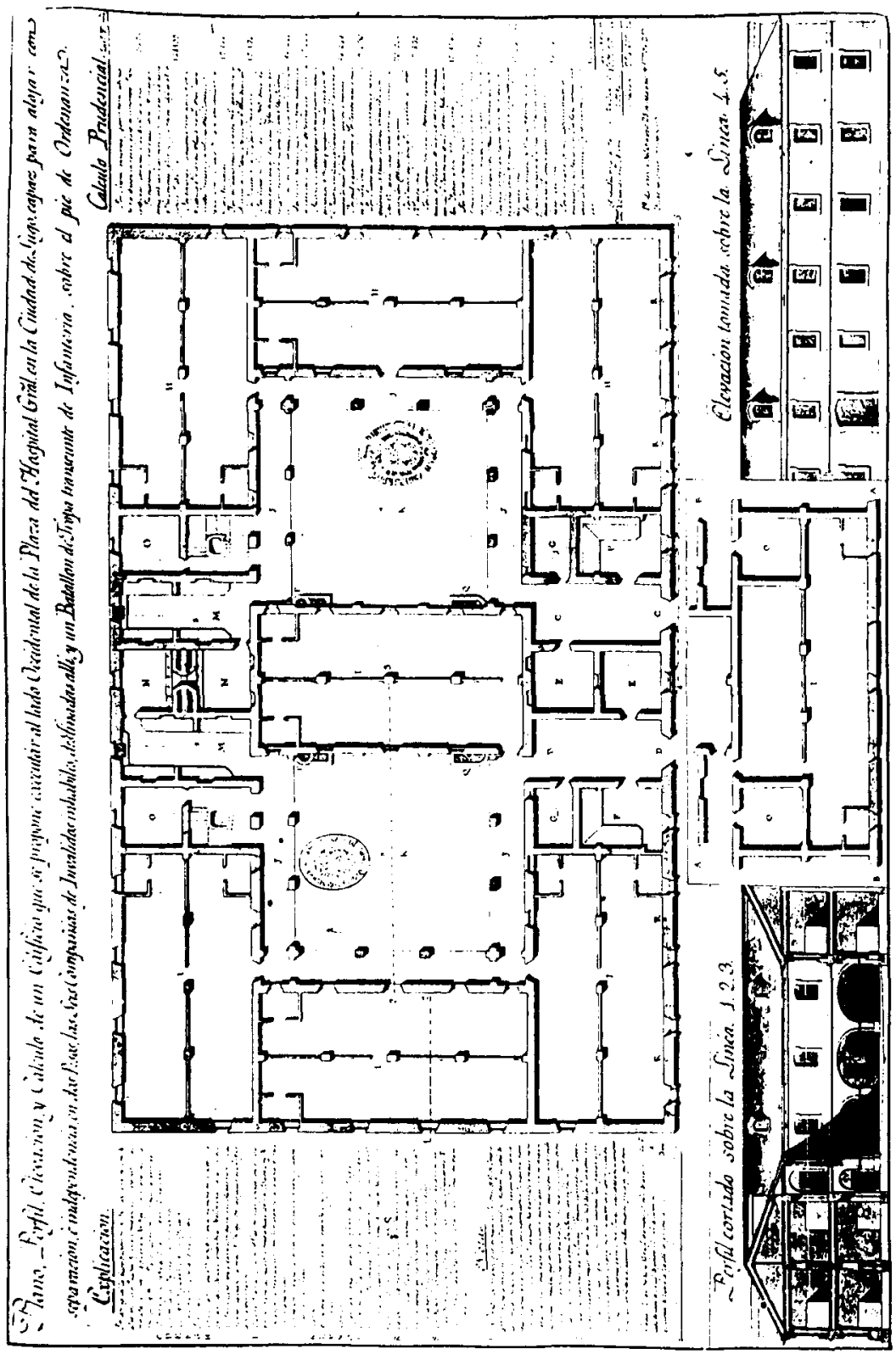

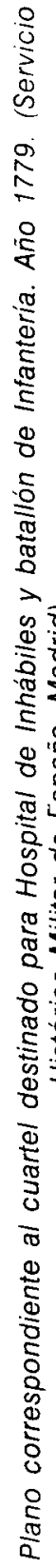

$\omega$

i) 
El capitán general envió a Lugo al ingeniero Feliciano Miguez para reconocer el terreno que estaba destinado para ubicar el cuartel, y ver la reducción de la obra. A través del agente de negocios en la corte, el Ayuntamiento sabía que las autoridades estaban conformes con que el cuartel fuese más pequeño, y que el dinero sobrante fuese empleado en el arreglo de las calles de la ciudad y en la reparación de la muralla.

El 29 de febrero de 1768, viendo el calamitoso estado en que se encontraban estas obras públicas, solicitaron del rey «que el cuartel que se hubiese de construir en ella fuese cómodo y reducido para el único efecto de inválidos a que lo ha solicitado, y lo que sobrase de su fábrica, y a que se redujese, se aplicase y determinase a los fines de composición de calles y reparos de murallas, como tan precisos a la conservación, aumento y felicidad de estos vasallos" ${ }^{38}$.

Para conseguir esta pretensión se recurrió al obispo fray Francisco Aramañá (1768-1786), que se encontraba en Madrid, para que "con sus superiores esfuerzos y valimiento" influyese en una resolución favorable por ser beneficiosa para el público, suplicándole “que condoliéndose del miserable estado en que se hallan calles y murallas, como dicho señor ilustrísimo lo ha palpado visiblemente, se sirva proteger el pensamiento de la ciudad a fin de que con su consecución se verifique el alivio de estos naturales" ${ }^{39}$.

Esta solicitud fue atendida, pasándose al Real y Supremo Consejo, que pidió informe a la Real Audiencia del Reino sobre las cantidades existentes procedentes del arbitrio y otros aspectos relacionados con la misma, tal como la valoración del coste de un cuartel más pequeño, reparación de la muralla y calles, levantándose el correspondiente plano.

La orden para el arreglo de las calles había sido dada por el Real Consejo el 22 de agosto de 1761, como consecuencia de haber acordado la Ciudad, Cabildo y obispo, la reducción a los desperfectos de las calles, decisión que fue recurrida por el procurador síndico general y por los cuatro gremios de la ciudad.

El 10 de noviembre de 1772, el Ayuntamiento hace una representación al rey poniendo en su conocimiento que, según sus noticias, peligraba la obra, ya que la importante cantidad que existía desde 1764 para atender su financiación, el intendente general pretendía que pasase a la tesorería

s8 Ibidem.

39 Leg. 93. Actas capitulares de 1768. Consistorio 25-02. AHP de L.A. 
del Ejército. Le pedían que esta disposición quedase sin efecto y que se construyese el cuartel.

Estos temores fueron aclarados por el conde de Ricla en un escrito enviado el 23 de diciembre desde El Escorial. Decía que el traspaso del dinero era un trámite necesario para los fines de su propia inversión. La tesorería del Ejército recibiera 285.586 reales y lo 06 maravedis, descontando 2.579 reales de gratificación. Los gastos de la cobranza importaron 2.404 reales y 03 maravedís. El adjudicatario de la recaudación del arbitrio, don Benito Pablo Díaz, debía 39.250 reales y 22 maravedís, por 10 que la cantidad real existente en diciembre de 1776 era de 322.257 reales y 28 maravedís.

Por fin, el 16 de octubre de 1779, se acuerda sacar a destajo el suministro de piedra pizarra para la obra, comprometiéndose a realizarlo Alonso Pereira y Vicente Fernández, que en lo que quedaba de año aportarian dos mil carros. El día 10 de octubre el teniente coronel de ingenieros, don Bartolomé Anphoux, ordenaba el comienzo de las obras con la adquisición de herramientas y acopio de materiales. Estuvieron bajo su dirección hasta que se trasladó al Campo de Gibraltar, sustituyéndolo don Fernando Caver.

Diez años después estaba terminado el edificio. El 27 de abril de 1790, se hizo la entrega oficial al Cuerpo de Inhábiles, por el ingeniero don Manuel Nadela. Habían transcurrido treinta y cuatro años desde el inicio de los trámites. Hubo un sobrante de 38.599 reales y 7 maravedís, de los que después serían utilizadas algunas cantidades para la construcción de varios armeros, en los que se pudiesen guardar los fusiles, perchas para las mochilas, y un canal para los comunes que por el carril del indigno, cruzando la Rúa Nova, pasase al de las Estantiguas.

Al edificio se le suprimió el tramo $S$, pero a pesar de ello era uno de los más importantes de la ciudad en cuanto a tamaño. Para los pisos se emplearon ciento treinta y dos vigas de madera de castaño bravo, dos mil trescientas cuarenta viguetas o pontones, y cuatro mil seiscientas tablas de castaño, entre otros materiales. Para la armadura de la cubierta se utilizaron seiscientas vigas de distintos tamaños. Las ventanas eran ciento ochenta, y las puertas veinticinco.

\section{DESCRIPCIÓN DEL EDIFICIO}

El edificio es muy sobrio. Está en consonancia con una de las corrientes racionalistas del neoclasicismo: predominio de los volúmenes y vanos rectos. La única conexión con los estilos anteriores, son algunos arcos 
de medio punto del cuerpo inferior del patio o claustro y de otras estancias del interior del edificio. La ausencia de decoración es total, y sólo las orejeras sobre los dinteles de las ventanas, rompen la linealidad manteniéndose un nexo estilístico con el barroco. Para la ejecución del edificio se van a seguir los planos de 1756, aunque con algunas modificaciones.

En los planos más antiguos que se conservan de la ciudad, como el de Pedro Menchaca y Saturnino Castilla, hacia 1836, así como el de Coello de 1864, aparece la planta de un edificio cuadrangular, con un patio central abierto por el lado $\mathrm{S}$. El edificio estaba formado por un tramo orientado al $\mathrm{N}$, de 59 varas de largo, unos $49 \mathrm{~m}, 14$ varas y 6 pulgadas de ancho, unos $13 \mathrm{~m}$, de cuyos extremos saldrían otros dos tramos de 51 varas, unos $42 \mathrm{~m}$, con sus fachadas orientadas al $E$ y al $W$ respectivamente. La altura del edificio, en sus tres costados era de 12 varas, unos 10 metros, $y$ en los dos testeros o frentes de 13,5 varas, unos $11 \mathrm{~m}$.

Ante la parte abierta del patio se formaba una pequeña plaza, desaparecida en la actualidad al hacerse el cuarto tramo. Este lado se cerraba con un pequeño muro. El terreno era «propio del rey que existe por el frente del cuartel, en la parte abierta que mira a lo interior de la ciudad, y tiene cincuenta y ocho varas de largo, y veinticuatro de ancho, por 10 que será de la obligación de la guardia el no permitir que ningún particular pueda habilitarse ni hacer alguna especie de obra en los terrenos que quedan demarcados" ${ }^{40}$.

Al ser el edificio de planta central, en el interior se formaba un patio con su claustro, de dos cuerpos, el inferior con arcadas de arcos carpaneles, aunque hay alguno de medio punto en los lados mayores, y el superior, con vanos adintelados que formaban la crujía o corredor.

Los materiales utilizados fueron la pizarra para los muros y el granito para las esquinas, pilastras, cepas, arcos, columnas, cornisas, puertas ventanas y partes principales del edificio. Los paramentos estaban revocados y caleados, y la carpintería pintada de encarnado.

El pavimento interior estaba formado por losas de pizarra, y los pisos superiores de tabla de castaño. En el piso bajo había al exterior veintidós ventanas de una altura de 2 varas, 2 pies y 3 pulgadas, unos $2,20 \mathrm{~m}$, y su ancho de 1 vara, 1 pie y 3 pulgadas, $1,25 \mathrm{~m}$, lo que hacía que las ventanas de madera tuviesen que llevar cada una diez bisagras. Por el exterior se protegieron con rejas de hierro, compuestas por cinco barrones macho y cuatro hembras.

${ }^{40}$ Leg. 8-9. Obras Públicas. AHP de L.A. 

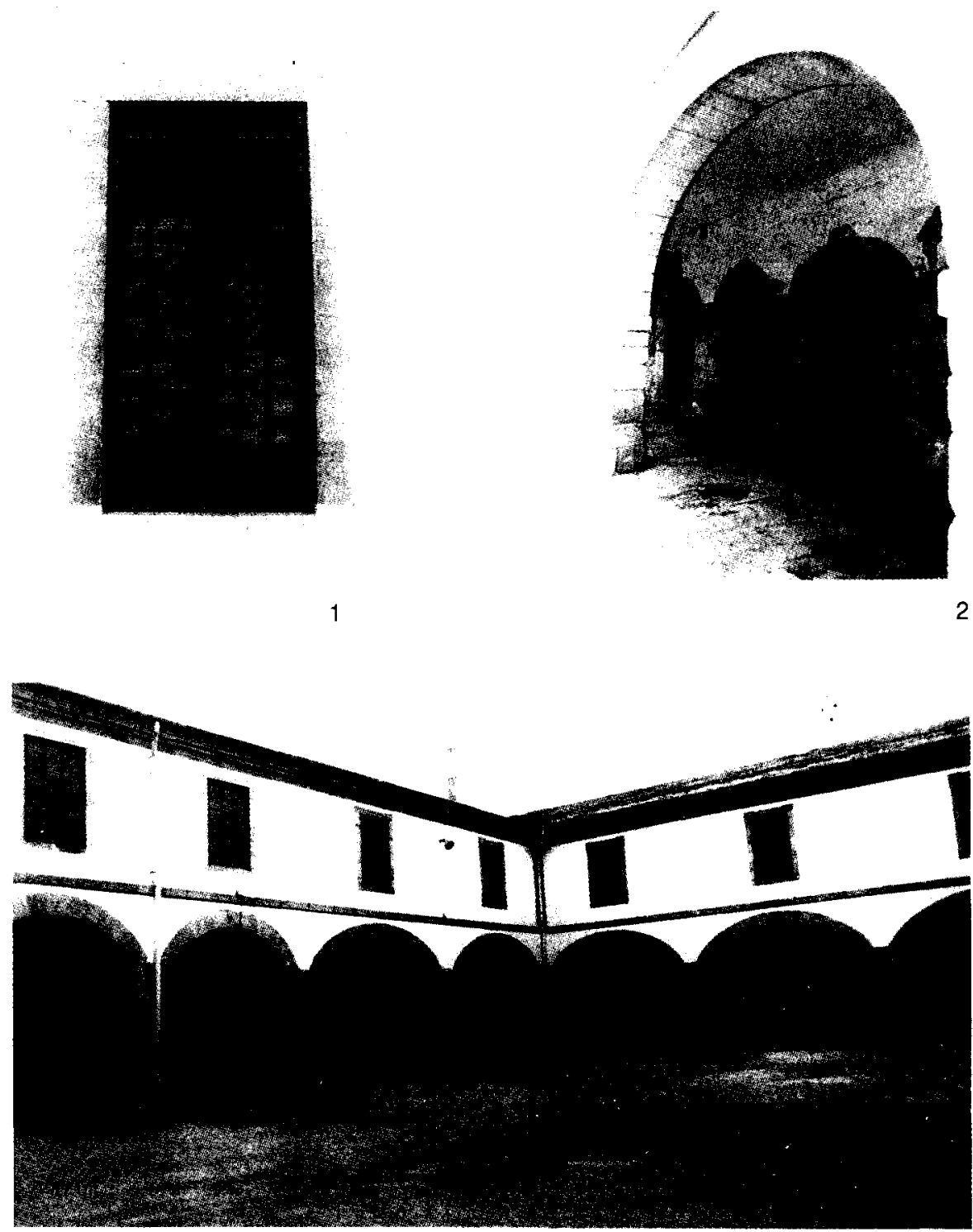

Fig. 6. 1. Vano con orejeras en el dintel, reminiscencia del barroco.

2. Accesos a las antiguas cocinas. Se combina el arco de medio punto y el carpanel.

3. Detalle del claustro o patio interior. 

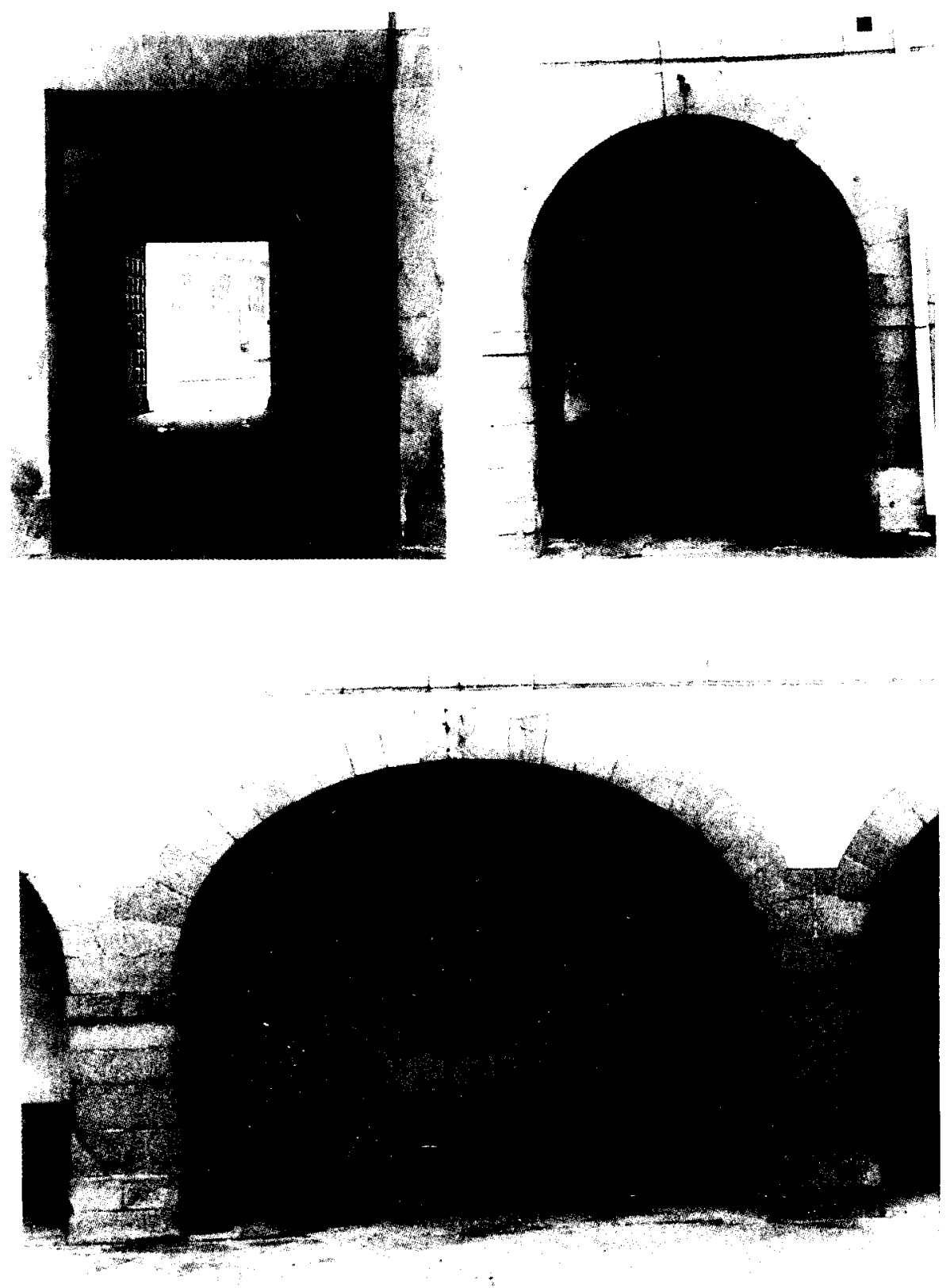

Fig. 7. Distintos tipós de vanos. El arco carpanel y el de medio punto, juega con el adintelado. 
La puerta principal se encontraba dando frente al hospital. Era de 4 varas y 5,5 pulgadas de alto, unos $3,4 \mathrm{~m}$, y de 3 varas y 2 pulgadas de ancho, unos $3,5 \mathrm{~m}$, dando acceso a un portal en el que estaba el cuerpo de guardia. También había un calabozo, el cuerpo del oficial de guardia, tres cuadras para habitación de la tropa, un cuarto para almacén de la leña, una cocina con cuatro chimeneas sostenidas por ocho columnas, tres fregaderos de cantería, dos piezas de letrinas, con doce asientos, comunicadas con dos escaleras de cinco gradas cada una.

Al piso central se accedía por una escalera de cantería de quince gradas en su primer tramo, y cinco de madera en el segundo, con su correspondiente barandilla y balaustres. Este piso tenía al exterior veintitrés ventanas de 2 varas, 1 pie y 2 pulgadas de alto, unos $2 \mathrm{~m}$, y 1 vara, 1 pie y 2 pulgadas de ancho, $1 \mathrm{~m}$. En el corredor que daba al patio había nueve ventanas.

En esta planta existía una habitación para un oficial, una cocina con cuatro chimeneas sostenidas en ocho columnas y dos fregaderos, las letrinas con doce asientos, y cuatro cuadras para habitación de la tropa. Al desván se accedía por una escalera de dieciocho gradas de madera, con barandilla y balaustres. 